\title{
THE EFFECTIVENESS OF IMPLEMENTING LAW NUMBER 23 OF 2004 ON ELIMINATION OF VIOLENCE IN HOUSEHOLD: CASE STUDY IN MAKASSAR CITY
}

\author{
A. Dewi Vitasari ${ }^{1 *}$, Hambali Thalib ${ }^{2}$, Sufirman Rahman ${ }^{2}$ \\ ${ }^{1}$ Student of Master of Law Science Program, Universitas Muslim Indonesia, Makassar \\ ${ }^{2}$ Professor of the Faculty of Law, Universitas Muslim Indonesia, Makassar \\ *Correspondence Author: A. Dewi Vitasari \\ Email Correspondence: avitasari.95@gmail.com
}

\begin{abstract}
This study aims to determine the effectiveness of implementing Law Number 23 of 2004 on Elimination of Violence in Household, as well as the factors that influence its enforcement. This type of research is empirical legal research with a quantitative descriptive in nature. This research was conducted in Makassar City to be precise at the Makassar City Police. The data collection techniques used in this study were questionnaires, documentation, and literature study. The data analysis technique used is quantitative data analysis techniques. The results showed that the implementation of Law No. 23 of 2004 in Makassar City is still considered less effective. Factors affecting the effectiveness of the implementation of Law No. 23 of 2004 in Makassar City consists of several factors, namely: legal factors; law enforcement factors; supporting facility factors; environmental factors; and cultural factors. in addition, environmental factors are the biggest factor affecting the effectiveness of the implementation of Law No. 23 of 2004. It is hoped that the police will further strengthen environmental factors in order to increase the effectiveness of the implementation of Law No. 23 of 2004 in the future.
\end{abstract}

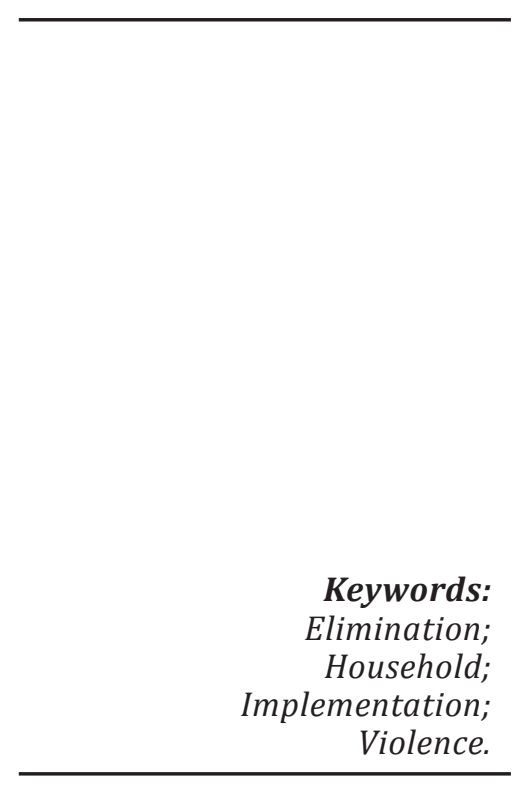

Articles with open access under a CC BY SA-4.0 license

\section{INTRODUCTION}

Building a household is the dream of every couple in this world, especially those who want to form a happy family (Saidiyah \& Julianto, 2016). A family that is peaceful, safe, and secure is the goal of every human being in living his household life, but not all families can live it as expected (Jajuli, 2017). However, if domestic life is colored with violence, then harmony in the household will not be realized (Tarmizi, Alamsyah, \& Syarifuddin, 2017). Furthermore, domestic violence also creates problems that extend to the social, national, and state domains (Etwiory, 2012). Therefore, all forms of violence must receive special attention from the State to create equality and justice (Risdianto, 2017). 
Recent developments indicate that acts of physical, psychological, and sexual violence in the household are still very common in society (Santoso \& Arifin, 2016). This condition can occur in husbands, wives, and children. This is a social problem that is difficult to overcome so that real action is needed in the form of law enforcement related to eliminating violence in households (Missa, 2013).

The increase in violence in the household has raised concerns for some people, nongovernment organizations, and other legal aid organizations, who are motivated to protect victims of violence in the household by submitting a bill on the elimination of violence (Pratiwi, 2017). Violence in the household finally presented Law of the Republic of Indonesia Number 23 of 2004 on Elimination of Violence in Household (hereinafter referred to as Law No. 23 of 2004) on September 22, 2004.

In the general explanation of Law No. 23 of 2004, it is explained that the intactness and harmony of a household that is happy, safe, secure, and peaceful constitute the desire of anyone in the household. Therefore, the State and society must work together in implementing prevention, protection, and prosecution of perpetrators of violence in the household (Utami, 2018).

With the enactment of Law No. 23 of 2004, it is hoped that it can be used as an adequate legal instrument, which includes provisions for prevention, protection of victims, and prosecution of perpetrators while maintaining family integrity (Leasa, 2018).

As a law requiring special regulation, apart from containing provisions regarding criminal sanctions, this law also regulates procedural law, the state's obligation to provide direct protection to victims who report (Jamaa, 2014). Thus it can be said that this provision is a legal breakthrough which is very important for efforts to uphold human rights, especially the protection of those who have been disadvantaged in a family or household structure (Juliani \& Wibowo, 2019).

Based on the description above, the purpose of this study is to the effectiveness of implementing Law No. 23 of 2004, as well as the factors that influence its enforcement.

\section{METHOD}

This research is empirical legal research with a quantitative descriptive in nature, which is research that views law in its social context (Sampara \& Husen, 2016), and is related to the effectiveness of implementing Law No. 23 of 2004 on Elimination of Violence in Household. This research was conducted in Makassar City to be precise at the Makassar City Police, with the considering that in the research location, there were many criminal acts of violence in the household. The population in this study were police, judges, prosecutors, advocates, defendants, victims, and activists from non-governmental organizations (NGOs).

The number of samples was 50 respondents who were determined and randomized proportionally, namely: 
1. Police as many as 15 people;

2. Judges as many as 5 people;

3. Prosecutors as many as 5 people;

4. Advocates as many as 5 people;

5. Defendants as many as 5 people;

6. Victims as many as 5 people;

7. NGO activist as many as 10 people.

The types of data used in this study are as follows:

1. Primary Data is data obtained directly from respondents based on population and sample determination;

2. Secondary Data is data obtained from tracing legal literature materials in the form of official documents of the Makassar Police, laws and regulations, references, legal scientific journals, legal encyclopedias, and official texts or publications.

The data were obtained using data collection techniques, namely:

1. Questionnaire, namely conducting direct interviews by asking questions that will be answered by respondents regarding the problems studied in this study;

2. Documentation, done by officially requesting related documents;

3. Literature study carried out by taking inventory and analyzing legal literature material related to the problem understudy in the study.

The data that has been collected is then quantified using a quantitative descriptive analysis model, then described through a frequency distribution table (Husen et al., 2020).

\section{RESULTS AND DISCUSSION}

\section{A. Theory of Legal Effectiveness}

Rahardjo (2005) argues that adequate law not only views law as a set of rules and principles governing human life in society but also must include the institutions and processes needed to realize law.

According to Soekanto (2004), legal effectiveness is a condition in which the applicable law can be implemented, obeyed, and effective as a means of social control or in accordance with the objectives of law formation. This situation can be reviewed based on several measures of effectiveness. Soekanto (1985) states that the factors that affect legal effectiveness are:

1. Legal factors;

2. Law enforcement factors;

3. Supporting facility factors;

4. Environmental factor; and

5. Cultural factors. 
These five factors are the essence as well as a measure of the effectiveness of law enforcement (Soekanto, 1985). It takes a systematics of the five factors, so that Law No. 23 of 2004 can be implemented effectively to ensure law enforcement in Indonesia.

\section{B. Violent Crime}

\section{Definition of Violence}

Violence comes from the word "vi" or "vis" which means power or rule. Violence, in the basic principles of Roman public and private law, is a physical or verbal act that reflects aggression and attacks on a person's freedom or dignity that can be carried out by an individual or group of people with authority. Furthermore, if translated literally, it can be interpreted as all authority regardless of legality. The use or act of arbitrariness can also be included in this formulation of violence. The roots of violence can be likened to wealth without work, pleasure without conscience, knowledge without character, trade without morality, science without humanity, worship without sacrifice, politics without principles (Sianturi, 1983). There are several definitions of violence, namely:

According to Sugiono (2008):

"Violence is all the actions of a person or group of people that cause injury to death, cause physical damage or property loss to others."

According to Sianturi (1983):

"Violence is take physical measures strenuous enough to cause the other person to become sick or helpless."

Article 89 of Law of the Republic of Indonesia Number 1 of 1960 on the Criminal Code (hereinafter referred to as Law No. 1 of 1960), regulates that:

"The commission of violence is identified with bringing a person in a state of unconsciousness or helplessness"

Based on the description above, a criminal act of violence is an act that uses physical violence or means against the law and violates the law which causes a person to faint, is helpless, or causes a person to die.

\section{Violence in the Book of Law}

In the second book of Law No. 1 of 1960, violence is divided into 5 (five) types (Rayhan, 2008), namely:

a. Ordinary maltreatment

This type of maltreatment is based on Article 351 of Law No. 1 of 1960, regulates that:

(1) Maltreatment shall be punished with a maximum imprisonment of two years and eight months .... 
(2) If the act results in a serious physical injury, the offender shall be punished with a maximum imprisonment of five years.

(3) If the fact results in death, he shall be punished by a maximum imprisonment of seven years.

(4) With maltreatment shall be identified intentional injury to the health.

(5) Attempt to this crime shall not be punished.

b. Light maltreatment

This type of maltreatment is based on Article 352 of Law No. 1 of 1960, regulates that:

(1) ... maltreatment that does not result in an illness or obstacle in the performance of official or professional activities, shall, as light maltreatment, be punished with a maximum imprisonment of three months ... . This sentence may be enhanced with one third in respect of the offender, who commits the crime against a person who is in service with him or who is his subordinate.

(2) Attempt to this crime shall not be punished.

c. Maltreatment committed with premeditation

This type of maltreatment is based on Article 353 of Law No. 1 of 1960, regulates that:

(1) Maltreatment committed with premeditation shall be punished with a maximum imprisonment of four years.

(2) If the fact results in a serious physical injury, the offender shall be punished by a maximum imprisonment of seven years.

(3) If the fact results in death, he shall be punished by a maximum imprisonment of nine years.

d. Serious maltreatment

This type of maltreatment is based on Article 354 of Law No. 1 of 1960, regulates that:

(1) The person who deliberately causes to another serious physical injury, shall, being guilty of serious maltreatment, be punished by a maximum imprisonment of eight years.

(2) If the fact results in death, the offender shall be punished by a maximum imprisonment of ten years.

e. Serious maltreatment committed with premeditation

This type of maltreatment is based on Article 355 of Law No. 1 of 1960, regulates that: 
(1) Serious maltreatment committed with premeditation shall be punished by a maximum imprisonment of twelve years.

(2) If the fact results in death, the offender shall be punished with a maximum imprisonment of fifteen years.

Law No. 23 of 2004 specifically regulates the prevention and protection and recovery of victims of violence in household with elements of a crime that is different from the criminal act of maltreatment that is regulated in the Law No. 1 of 1960.

\section{Violence in Law No. 23 of 2004 on Elimination of Violence in Household}

The household (family) is the foundation of a country because from that family the future generations of the nation will be born. When the family breaks down, the country's existence is dangerous. Thus, violence in the household is one of the factors that damage the family so that it affects all members of society.

Based on Article 1 point 1 of Law No. 23 of 2004, explain that:

"Violence in Household shall be any act against anyone particularly woman, bringing about physical, sexual, psychological misery or suffering, and/or negligence of household including threat to commit act, forcing, or seizure of freedom in a manner against the law within the scope of household."

Furthermore, based on Article 5 of Law No. 23 of 2004, regulates that anyone shall be prohibited to carry out violence in household against an individual within the scope of the household, be means of:
a. physical violence;
b. psychic violence;
c. sexual violence; or
d. negligence of household.

\section{Scope of Crime of Violence in Household}

The scope of the household as based on Article 356 of Law No. 1 of 1960, namely: his mother, his lawful father, his spouse or his child. Furthermore, as based on Article 2 of Law No. 23 of 2004, regulates that:

(1) The scope of household in this Law shall include:

a. husband, wife, and children;

b. people whose family relationship with the individual referred to under letter a is due to blood relationship, marriage, suckling at the same breast, care, and guardianship, who lives in the household; and/or

c. the individual working to assist the household and living in the household.

(2) People working ... shall be considered as family member during the period while living in the household in question. 
Vitasari, A. Dewi, et al., The Effectiveness of Implementing Law Number 23 of 2004 ...

The term violence in household is related to housewives or wives as victims. The term violence in household in Western literature is generally used in a number of ways, such as violence in household and wife abuse (Martha, 2003).

\section{The Effectiveness of Law No. 23 of 2004 in Makassar City}

Households as based on Article 1 Point 30 of Law of the Republic of Indonesia Number 8 of 1981 on the Code of Criminal Procedure (hereinafter referred to as Law No. 8 of 1981), explain that "family is those who have blood relationships to a certain degree or marital relationships". It's just that based on Article 2 of Law No. 23 of 2004, the scope of the family has expanded its meaning.

Based on the research that has been carried out regarding the effectiveness of implementing Law No.23 of 2004 in Makassar City, the following is a report on violence in the household for three years (2018-2020), including the following:

Table 1. Data on Violence in Household in Makassar City 2018-2020

\begin{tabular}{c|c|c|c|c}
\hline \hline \multirow{2}{*}{ Type of Cases } & \multicolumn{3}{|c|}{ Cases/Year } & \multirow{2}{*}{ Total } \\
\cline { 2 - 4 } & $\mathbf{2 0 1 8}$ & $\mathbf{2 0 1 9}$ & $\mathbf{2 0 2 0}$ & \\
\hline \hline Maltreatment & 14 & 16 & 32 & 62 \\
\hline Violence Against Children & 9 & 28 & 28 & 65 \\
\hline Sexual Violence & 7 & 8 & 11 & 26 \\
\hline \hline Negligence of Household & 5 & 5 & 6 & 16 \\
\hline Total & $\mathbf{3 5}$ & $\mathbf{5 7}$ & $\mathbf{7 7}$ & $\mathbf{1 6 9}$ \\
\hline \hline
\end{tabular}

Source: Makassar City Police, 2020

Based on the data above, cases of violence in household have increased from year to year. In 2018, there were 35 cases of violence in household that were submitted to the Makassar City Police, consisting of 14 cases of maltreatment, 9 cases of violence against children, 7 cases of sexual violence, and 5 cases of negligence of household.

In 2019, there were 57 cases of violence in household that were submitted to the Makassar City Police, consisting of 16 cases of maltreatment, 28 cases of violence against children, 8 cases of sexual violence, and 5 cases of negligence of household.

Meanwhile, in 2020, there were 77 cases of violence in household that were submitted to the Makassar City Police, consisting of 32 cases of maltreatment, 28 cases of violence against children, 11 cases of sexual violence, and 6 cases of negligence of household.

Violence against children was the largest case in violence in household from 2018 to 2020 with 65 cases, followed by maltreatment with 62 cases, sexual violence with 26 cases, and negligence of household with 16 cases.

From the data above, it can be seen that the cases of domestic violence that mostly occur in Makassar City are violence against children. These types of violence can take the form of abuse, beatings, or other physical violence. 
The legal rules governing violence in household are clear, namely all the provisions in Law No. 23 of 2004. Soekanto (1985) states that:

"The rule of law can be effective if it meets the requirements of law enforcement, namely: juridically, sociologically, and philosophically. If these three aspects are fulfilled, then the law will be easily enforced."

The results of the data were obtained from interviews with respondents regarding the effectiveness of the implementation of Law No. 23 of 2004, can be seen in the table below.

Table 2. The Effectiveness of Law No. 23 of 2004 in Makassar City

\begin{tabular}{c|c|c}
\hline \hline Indicator & Frequency & Percentage (\%) \\
\hline \hline Effective & 15 & $30 \%$ \\
\hline Less Effective & 28 & $56 \%$ \\
\hline Ineffective & 7 & $14 \%$ \\
\hline \hline Total & $\mathbf{5 0}$ & $\mathbf{1 0 0 \%}$ \\
\hline \hline
\end{tabular}

Data Source: Processed from a Questionnaire, 2020

The table above shows that there are 15 people or $30.00 \%$ of respondents who stated that they were effective; 28 people or $56.00 \%$ of respondents who stated that they were less effective; and 7 people or $14.00 \%$ of respondents who stated they were ineffective. Implementation of Law No. 23 of 2004 in Makassar City is still considered less effective.

The results of the table above are also in line with what Mirna (not her real name) expressed, that "I was often beaten for no reason by my ex-husband, even my son was often beaten. That's why I went to the police and chose to separate".

\section{E. Factors Affecting the Effectiveness of the Implementation of Law No. 23 of 2004 in Makassar City}

The results of obtaining data from the interview process with respondents related to the Factors Affecting the Effectiveness of the Implementation of Law No. 23 of 2004 in Makassar City, can be seen in the table below.

Table 3. Factors Affecting the Effectiveness of the Implementation of Law No. 23 of 2004 in Makassar City

\begin{tabular}{l|c|c}
\hline \hline \multicolumn{1}{c||}{ Factors Affecting } & Frequency & Percentage (\%) \\
\hline \hline Legal Factors & 9 & $18 \%$ \\
\hline Law Enforcement Factors & 10 & $20 \%$ \\
\hline Supporting Facility Factors & 5 & $10 \%$ \\
\hline Environmental Factors & 18 & $36 \%$ \\
\hline \hline Cultural Factors & 8 & $16 \%$ \\
\hline \hline \multicolumn{1}{c|}{ Total } & $\mathbf{5 0}$ & $\mathbf{1 0 0 \%}$ \\
\hline \hline
\end{tabular}

Data Source: Processed from a Questionnaire, 2020 
Based on the data above, environmental factors are the biggest factor affecting the effectiveness of the implementation of Law No. 23 of 2004 where there are 18 people or $36.00 \%$ of respondents, followed by law enforcement factors where there are 10 people or $20.00 \%$ of respondents, legal factors where there were 9 people or $18.00 \%$ of respondents, cultural factors where there were 8 people or $16.00 \%$ of respondents, and supporting facility factors where there were 5 people or $10.00 \%$ of respondents.

\section{CONCLUSIONS}

Based on the description of the results and discussion, it can be concluded that the implementation of Law No. 23 of 2004 in Makassar City is still considered less effective. Factors affecting the effectiveness of the implementation of Law No. 23 of 2004 in Makassar City consists of several factors, namely: legal factors; law enforcement factors; supporting facility factors; environmental factors; and cultural factors. in addition, environmental factors are the biggest factor affecting the effectiveness of the implementation of Law No. 23 of 2004. Based on these conclusions, it is hoped that the police will further strengthen environmental factors in order to increase the effectiveness of the implementation of Law No. 23 of 2004 in the future.

\section{REFERENCES}

Etwiory, Herlina. (2012). Kajian Yuridis Kekerasan dalam Rumah Tangga (Suatu Studi tentang Hubungan Hukum Privat dan Hukum Publik). Lex Crimen: Jurnal Elektronik Bagian Hukum Pidana, Universitas Sam Ratulangi, 1(3), pp. 1-19.

Husen, La Ode, et al. (2020). Safeguard of the Police Intelligence Against Court Decisions Regarding the Object of the Dispute. Sovereign: International Journal of Law, CV. Social Politic Genius (SIGn), 2(2), pp. 1-12. doi: https://doi.org/10.37276/sijl.v2i2.28

Jajuli, Sulaeman. (2017). Fenomena Al-Syiqaq dalam Putusan Perkawinan di Pengadilan Agama Kota Bogor. Misykat al-Anwar Jurnal Kajian Islam dan Masyarakat, Universitas Muhammadiyah Jakarta, 28(1), pp. 1-20.

Jamaa, La. (2014). Perlindungan Korban Kekerasan dalam Rumah Tangga dalam Hukum Pidana Indonesia. Jurnal Cita Hukum, UIN Syarif Hidayatullah Jakarta, 2(2), pp. 249-272. doi: http://dx.doi.org/10.15408/jch.v1i2.1467

Juliani, Wenny \& Wibowo, Aji. (2019). Perlindungan Hukum bagi Perempuan Korban Kekerasan Nonfisik dalam Rumah Tangga Menurut UU No. 23 Tahun 2004 di DKI Jakarta. Jurnal Hukum Adigama, Universitas Tarumanagara, 2(1), pp. 1265-1289. doi: http://dx.doi.org/10.24912/adigama.v2i1.5282

Law of the Republic of Indonesia Number 1 of 1960 on the Criminal Code. (State Gazette of the Republic of Indonesia of 1960 Number 1, Supplement to the State Gazette of the Republic of Indonesia Number 1921).

Law of the Republic of Indonesia Number 8 of 1981 on the Code of Criminal Procedure. (State Gazette of the Republic of Indonesia of 1981 Number 76, Supplement to the State Gazette of the Republic of Indonesia Number 3209). 
Law of the Republic of Indonesia Number 23 of 2004 on Elimination of Violence in Household. (State Gazette of the Republic of Indonesia of 2004 Number 95, Supplement to the State Gazette of the Republic of Indonesia Number 4419).

Leasa, Elias Zadrach. (2018). Aspek Legal Spirit Undang-Undang Nomor 23 Tahun 2004 tentang Penghapusan Kekerasan dalam Rumah Tangga. SASI, Universitas Pattimura, 24(2), pp. 168-178. doi: https://doi.org/10.47268/sasi.v24i2.131

Martha, Aroma Elmina. (2003). Perempuan, Kekerasan, dan Hukum. Yogyakarta: UII Press.

Missa, Lamber. (2013). Studi Kriminologi Penyelesaian Kekerasan dalam Rumah Tangga di Kota Kupang. Kanun: Jurnal Ilmu Hukum, Universitas Syiah Kuala, 15(2), pp. 297-312.

Pratiwi, Andi Misbahul. (2017). Ninuk Widyantoro: The Importance of Education and Fulfillment of SRHR. Jurnal Perempuan, Yayasan Jurnal Perempuan, 22(2), pp. 165-172.

Rahardjo, Satjipto. (2005). Membedah Hukum Progresif. Jakarta: Kompas.

Rayhan, A. (2008). Kitab Undang-Undang Hukum Pidana (KUHP). Jakarta: Citra Wacana.

Risdianto, Danang. (2017). Perlindungan terhadap Kelompok Minoritas di Indonesia dalam Mewujudkan Keadilan dan Persamaan di Hadapan Hukum. Rechts Vinding Online, Kementerian Hukum dan Hak Azasi Manusia RI, 6(1), pp. 125-142.

Saidiyah, Satih \& Julianto, Very. (2016). Problem Pernikahan dan Strategi Penyelesaiannya: Studi Kasus pada Pasangan Suami Istri dengan Usia Perkawinan di Bawah Sepuluh Tahun. Jurnal Psikologi, Universitas Diponegoro, 15(2), pp. 124133. doi: https://doi.org/10.14710/jpu.15.2.124-133

Sampara, Said \& Husen, La Ode. (2016). Metode Penelitian Hukum. Makassar: Kretakupa Print.

Santoso, Lukman \& Arifin, Bustanul. (2016). Perlindungan Perempuan Korban Kekerasan Perspektif Hukum Islam. De Jure: Jurnal Hukum dan Syar'iah, Universitas Islam Negeri Maulana Malik Ibrahim, 8(2), pp. 113-125. doi: http:// dx.doi.org/10.18860/j-fsh.v8i2.3732

Sianturi, S. R. (1983). Tindak Pidana di KUHP Berikut Uraiannya. Jakarta: Alumni.

Soekanto, Soerjono. (1985). Efektivikasi Hukum dan Peranan Sanksi. Jakarta: PT. Remaja Rosdakarya.

Soekanto, Soerjono. (2004). Faktor-Faktor yang Mempengaruhi Penegakan Hukum. Jakarta: Rajawali Pers.

Sugiono, Dendy (Ed.) (2008). Kamus Besar Bahasa Indonesia: Pusat Bahasa. Jakarta: Departemen Pendidikan Nasional bekerjasama dengan PT. Gramedia Pustaka Utama.

Tarmizi, Ahmad, Alamsyah, Bunyamin, \& Syarifuddin, Amir. (2017). Tindak Pidana Kekerasan dalam Rumah Tangga yang Menjadi Alasan Putusnya Gugatan Perceraian di Pengadilan Agama Jambi. Legalitas: Jurnal Hukum, Universitas Batanghari, 9(2), pp. 248-308. 
Utami, Penny Naluria. (2018). Pencegahan Kekerasan terhadap Anak dalam Perspektif Hak Atas Rasa Aman di Nusa Tenggara Barat. Jurnal HAM, Badan Penelitian dan Pengembangan Hukum dan HAM, 9(1), pp. 1-17. doi: http://dx.doi.org/10.30641/ ham.2018.9.1-17

Vitasari, A. Dewi, et al. (2020). The Effectiveness of Implementing Law Number 23 of 2004 on Elimination of Violence in Household: Case Study in Makassar City. Sovereign: International Journal of Law, CV. Social Politic Genius (SIGn), 2(3), 1-11. doi: https://doi. ' I org/10.37276/sijl.v2i3.32 